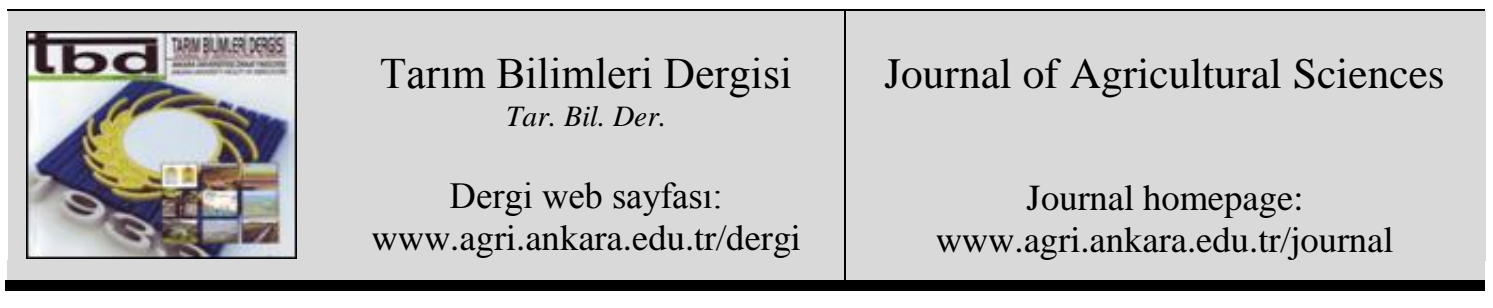

\title{
The Genetic Characterization of DGAT1 Gene in Donkey Populations Reared in Thrace Region of Turkey
}

\author{
Fulya ÖZDIL ${ }^{\text {a }}$

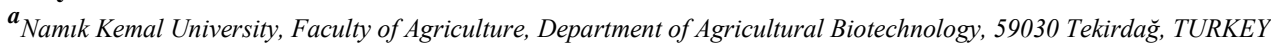

ARTICLE INFO

Research Article

Corresponding Author: Fulya ÖZDIL, E-mail: fozdil@nku.edu.tr, Tel: +90 (282) 2502233

Received: 05 August 2018, Received in Revised Form: 07 November 2018, Accepted: 20 November 2018

\section{AUTHORS ORCID ID}

(Fulya ÖZDIL: 0000-0002-5298-6997)

\begin{abstract}
AcylCoA: diacylglycerol acyltransferase (DGAT1) gene has a considerable effect on milk content and yield in cattle with a substitution of lysine by alanine in the exon 8 of the gene. Moreover there are many other researches comprising the $D G A T 1$ gene on different farm animals, such as buffalo, sheep and goat but there is no information about the DGAT1 gene in donkeys. In this study, the polymorphism of DGAT1 gene in donkey populations reared in Thrace region of Turkey has been investigated by restriction fragment length polymorphism (RFLP) via EaeI $(C f r \mathrm{I})$ restriction enzyme.
\end{abstract}

EaeI restriction site was found in cattle breeds which resulted after K232A substitution, Lysine (AAG) to Alanine (GCG) variant but this restriction site was not found in donkey populations. A novel single-nucleotide polymorphism ( $\mathrm{G} \rightarrow \mathrm{A}$ substitution) in the DGAT1 gene at position 10,435 lacks this restriction site which results only Alanine variant (GCA) instead of Lysine variant. This novel singlenucleotide polymorphism in the DGAT1 gene was found in the studied donkey breeds.

Keywords: DGAT1 Gene; RFLP; Equus asinus; Donkey; Turkey

\section{Introduction}

Triglycerides are mainly synthesized from diglycerides that DGAT1 is an enzyme that catalyzes a crucial role in mammalian triglyceride synthesis. DGAT1 enzyme acts an important role in lipogenesis pathway in many tissues (Cases et al 1998) so the DGATl gene, encoding this enyzme has been found relevant in milk production. In many of the studies, associations between DGAT1 gene polymorphism and milk composition and production traits have been investigated (Spelman et al 2002; Weller et al 2002; Thaller et al 2003; Gautier et al 2007). Fat is an important component of mammalian milk. DGAT1 gene is found as a potential candidate gene for milk fat yield in cattle (Schennink et al 2007). Moreover DGAT1 gene, is also a candidate gene, because it has been found at the centromere region of the bovine $14^{\text {th }}$ chromosome and includes 17 exons of variable sizes encoding a 489 amino acid protein that spans a quantitative trait locus (QTL) for milk production traits (Coppieters et al 1998; Grisart et al 2002). In the $8^{\text {th }}$ exon of DGAT1 gene $\left(10.433^{\text {th }}\right.$ and $10.434^{\text {th }} \mathrm{bp}$ ), two single-nucleotide polymorphisms (SNPs) have been reported and generated to QTL (quantitative trait loci) variation. These polymorphisms caused the substitution of lysine to alanine (K232A) and consulted to considerably affect the milk fat composition in cattle (Coppieters et al 1998; Winter et al 2002; Grisart et al 2002; 2004; Kaupe et al 2004). In DGAT1 gene, Alanine variant (A allele) and Lysine variant (K allele) were related with high milk yield and high milk fat yield in cattle, respectively (Coppieters et al 1998; Winter et al 2002; Grisart et al 2004). 
In many countries, donkey breeds which were used as pack animals in rural areas have become extinct or critically endangered. In the last years, donkey populations have declined dramatically in Turkey. All over the World, donkeys which are under threat of extinction, have to be characterized both morphologically and genetically in order to constitute conservation strategies. For the last years, donkey milk has been used as curative, reformative, nutritive substance as well as cosmetics. Due to its rich content, the scientific interest to donkey milk has been increased recently. Cow's milk allergy is an important problem in infants and many researches show exciting findings on equid (horse and donkey) milk tolerability (Salimei et al 2004). So the candidate gene, DGAT1, which is found in association with milk production traits, should be investigated in donkeys in order to identify the gene regulation of donkey milk genetic parameters. So the aim of this study was to search the DGAT1 gene in donkey populations reared in Thrace region of Turkey and introduce the variation in this gene region. Also the RFLP characterization of DGATl gene in donkeys was conducted for the first time in Turkey.

\section{Material and Methods}

In this study, 61 blood samples were collected from Thrace region of Turkey, Kirklareli Province. 41 samples were collected from a donkey farm in Koruköy Village and 10 samples each were collected from Üsküp and Kuzulu Villages. Blood samples were collected from the vena jugulars of the donkeys and used for the DNA extraction.

All DNA isolations were done according to phenol chloroform extraction method with slight modifications (Sambrook et al 1989). PCR reactions and cycling conditions were carried out as reported in Kaupe et al (2004) in a $25 \mu \mathrm{L}$ volume using $50 \mathrm{ng}$ of genomic DNA

437 bp of DGAT1 gene were amplified by Polymerase Chain Reaction (PCR) using the primers given in Kaupe et al (2004). To check whether the allelic variation that were reported in cattle, $\left(10.433^{\text {th }}-10.434^{\text {th }}\right.$ bp of the DGAT1 gene, Genbank Accession no. JF894305) was also found in donkeys; DGAT1 gene region amplification was digested with EaeI restriction enzyme (NEW England Biolabs Inc). The digested fragments were separated using 2\% agarose gels, stained with SYBRSafe DNA gel stain (Thermo Fisher Scientific) and visualized with Vilber Lourmat gel imaging system.

The DGAT1 genes of two samples were sequenced on an Applied Biosystems 3500XL Genetic Analyzer System (Applied Biosystems, USA) in order to verify the sequence variations of the EaeI restriction site.

\section{Results and Discussion}

The 437 bp of PCR products (including the primers) were amplified and digested with EaeI restriction enzyme. In all of the studied DNA samples uncut single band of $437 \mathrm{bp}$ were obtained (Figure 1).

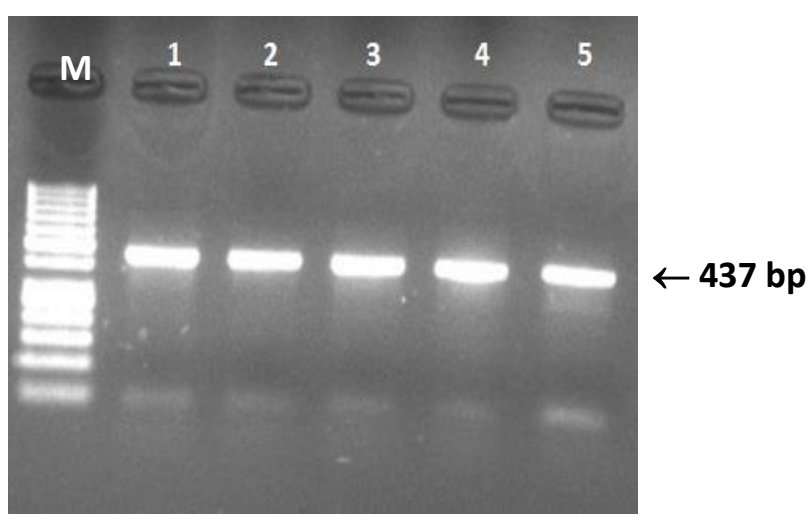

Figure 1- Undigested PCR products of DGAT1 gene (437 bp) via EaeI restriction enzyme in donkeys. M: 50 bp DNA ladder (Invitrogen 10416014) 
The sequencing of this region revealed polymorphisms when compared to cattle and buffalo DGAT1 gene sequences. In the $8^{\text {th }}$ exon of the gene, $10.433^{\text {th }}-10.434^{\text {th }}$ bp of the DGAT1 gene, two SNPs were reported in cattle which revealed two different alleles, Lysine ( $\underline{A} \underline{A} G)$ and Alanine $(\underline{G} \underline{C} G)$ alleles (Table 1). $\mathrm{A} \rightarrow \mathrm{G}$ and $\mathrm{A} \rightarrow \mathrm{C}$ base substitutions revealed EaeI recognition site and Alanine allele was obtained. Genbank records of these alleles are given in Table 1. The DNA sequence of this gene region in donkey revealed again Alanine allele, $\mathrm{A} \rightarrow \mathrm{G}$ and $\mathrm{A} \rightarrow \mathrm{C}$ base substitutions at position 10,433 and 10,434 were again determined but also a novel polymorphism at $10.435^{\text {th }}$ of the DGAT1 gene, $\mathrm{G} \rightarrow \mathrm{A}$ transition which also revealed Alanine (GCㅡ) allele was obtained but this substitution resulted the loss of EaeI restriction site. As a result, no EaeI restriction in DGAT1 gene was obtained in donkey populations.

Table 1- Allelic variation of EaeI restriction site in DGAT1 gene in cattle, buffalo and donkeys

\begin{tabular}{lcccccccccc}
\hline $\begin{array}{l}\text { Nucleotide } \\
\text { positions } \\
\begin{array}{l}\text { Genbank no: } \\
\text { AJ318490) }\end{array}\end{array}$ & 10433 & 10434 & 10435 & 10436 & 10437 & 10438 & 10439 & Allele & $\begin{array}{c}\text { Genbank } \\
\text { accession no } \\
\text { restriction }\end{array}$ \\
\hline Cattle & $\mathrm{G}$ & $\mathrm{C}$ & $\mathrm{G}$ & $\mathrm{G}$ & $\mathrm{C}$ & $\mathrm{C}$ & $\mathrm{A}$ & Alanine (A) & EU348567 & + \\
Cattle & $\mathrm{A}$ & $\mathrm{A}$ & $\mathrm{G}$ & $\mathrm{G}$ & $\mathrm{C}$ & $\mathrm{C}$ & $\mathrm{A}$ & Lysine (K) & EU077528 \\
Buffalo & $\mathrm{A}$ & $\mathrm{A}$ & $\mathrm{G}$ & $\mathrm{G}$ & $\mathrm{C}$ & $\mathrm{C}$ & $\mathrm{A}$ & Lysine (K) & JQ627609 \\
Donkey & $\mathrm{G}$ & $\mathrm{C}$ & $\mathrm{A}$ & $\mathrm{G}$ & $\mathrm{C}$ & $\mathrm{C}$ & $\mathrm{A}$ & Alanine (A) & NW_014638167 & - \\
\hline
\end{tabular}

EaeI (CfrI) restriction Site: (T/C)GGCC(A/G) 10434 to 10439

\section{Conclusions}

Around the middle of the $20^{\text {th }}$ century, as a consequence of industrialization in agriculture and the spreading several highly selected breeds, many animal populations have become extinct or are declining and endangered. In many countries, donkey breeds which were used as pack animals in rural areas have become extinct or critically endangered. In the last years, donkey populations have declined dramatically in Turkey (Anonymous 2018). So both morphological and genetic studies have to be conducted on Turkish native donkey breeds.

In this study, we used PCR-RFLP method by EaeI restriction enzyme of DGAT1 gene to introduce the genetic polymorphism in donkey populations from Thrace region of Turkey. The $437 \mathrm{bp}$ of DGAT1 gene were amplified and digested with EaeI restriction enzyme and no restriction site was obtained in Turkish donkey populations as well as Anatolian buffalo populations (Özdil \& İlhan 2012).

The sequencing of this region revealed polymorphisms when compared to cattle and buffalo DGAT1 gene sequences. In the $8^{\text {th }}$ exon of the gene, $10.433^{\text {th }}-10.434^{\text {th }}$ bp of the DGATl gene, two SNPs were reported in cattle which revealed two different alleles, Lysine and Alanine alleles (Table 1). The DNA sequence of this gene segment in donkeys revealed Alanine allele, $\mathrm{G}$ and $\mathrm{C}$ at position 10.433 and 10.434, respectively, but also produced a novel polymorphism at position $10.435, \mathrm{G} \rightarrow \mathrm{A}$ which also revealed Alanine allele but without EaeI digestion.

In many of the studies, DGAT1 gene is indicated as a functional candidate gene that has a substitution of lysine by alanine (K232A) allele generating a fundamental effect on milk fat composition and yield (Coppieters et al 1998; Smith et al 2000; Winter et al 2002; Grisart et al 2002; 2004). In DGAT1 gene while Lysine (AAG) variant (K allele) was related with high fat percentage of milk, Alanine variant (A allele) of this gene was related with high milk yield (Winter et al 2002; Grisart et al 2002; 2004). Also K allele reported to be the wild type allele (Coppieters et al 1998; Grisart et al 2002; Kaupe et al 2004). In this study only Alanine allele which is responsible for high milk yield in cattle, is found in donkeys. Also a novel polymorphism $(\mathrm{G} \rightarrow \mathrm{A})$ at position 10.435 bp of the DGATl gene is reported in donkey populations. This study provides an insight to donkey genetics and indirect evidence that all of the Thrace donkey populations in Turkey have fixed allele with respect to DGAT1 Alanine allele. 


\section{References}

Anonymous (2018). Turkish Statistical Institude. Animal statistics database. Retrieved in May, 10, 2018 fromhttps://biruni.tuik.gov.tr/hayvancilikapp/hayvancilik.zul

Cases S, Smith S J, Zheng Y W, Myers H M, Lear S R, Sande E, Novak S, Collins C, Welch C B, Lusis A J, Erickson S K \& Farese Jr R V (1998). Identification of a gene encoding an acyl CoA:diacylglycerol acyltransferase, a key enzyme in triacylglycerol synthesis. Proceedings of the National Academy of Sciences of the United States of America USA 95: 13018-13023

Coppieters W, Riquet J, Arranz J J, Berzi P, Cambisano N, Grisart B, Karim L, Marcq F, Moreau L, Nezer C, Simon P, Vanmanshoven P, Wagenaar D \& Georges M (1998). A QTL with major effect on milk yield and composition maps to bovine chromosome 14. Mammalian Genome 9: 540-544

Gautier M, Capitan A, Fritz S, Eggen A, Boichard D \& Druet T (2007). Characterization of the DGAT1 K232A and variable number of tandem repeat polymorphisms in French dairy cattle. Journal of Dairy Science 90: 2980-2988

Grisart B, Coppieters W, Farnir F, Karim L, Ford C, Berzi P, Cambisano N, Mni M, Reid S, Simon P, Spelman R, Georges M \& Snell R (2002). Positional candidate cloning of a QTL in dairy cattle: identification of a missense mutation in the bovine DGAT1 gene with major effect on milk yield and composition. Genome Research 12: 222231

Grisart B, Farnir F, Karim L, Cambisano N, Kim J J, Kvasz A, Mni M, Simon P, Frère J M, Coppieters W \& Georges M (2004). Genetic and functional confirmation of the causality of the DGAT1 K232A quantitative trait nucleotide in affecting milk yield and composition. Proceedings of the National Academy of Sciences of the United States of America 101: 2398-2403

Kaupe B, Winter A, Fries R \& Erhardt G (2004). DGAT1 polymorphism in Bos indicus and Bos Taurus cattle breeds. Journal of Dairy Research 71: 182-187

Özdil F \& İlhan F (2012). DGAT1-exon 8 polymorphism in Anatolian buffalo. Livestock Science 149: 83-87.

Salimei E, Fantuz F, Coppola R, Chiofalo B, Polidori P \& Varisco G (2004). Composition and characteristics of ass's milk. Animal Research 53: 67-78

Sambrook J, Fritsch E F \& Maniatis T (1989). Molecular cloning: A laboratory Manual, vol. 3, Cold Spring Harbor Laboratory Press, Cold Spring Harbor, N.Y

Schennink A, Stoop W M, Visker M H P W, Heck J M L, Bovenhuis H, van der Poel J J, van Valenberg H J F \& van Arendonk J A M (2007). DGAT1 underlies large genetic variation in milk-fat composition of dairy cows. Animal Genetics 38: 467-473

Smith S J, Cases S, Jensen D R, Chen H C, Sande E, Tow B, Sanan D A, Raber J, Eckel R H \& Farese R V.Jr (2000). Obesity resistance and multiple mechanisms of triglyceride synthesis in mice lacking Dgat. Nature Genetics 25 : $87-90$

Spelman R J, Ford C A, McElhinney P, Gregory G C \& Snell R G (2002). Characterization of the DGAT1 gene in the New Zealand dairy population. Journal of Dairy Science 85: 3514-3517

Thaller G, Krämer W, Winter A, Kaupe B, Erhardt G \& Fries R (2003). Effects of DGAT1 variants on milk production traits in German cattle breeds Journal of Animal Science 81: 1911-1918

Weller J I, Golik M, Seroussi E, Ezra E \& Ron M (2002). Population-wide analysis of a QTL affecting milk-fat production in the Israeli Holstein population. Journal of Dairy Science 86: 2219-2227

Winter A, Kramer W, Werner F A O, Kollers S, Kata S, Durstewitz G, Buitkamp J, Womack J E, Thaller G \& Fries R (2002). Association of a lysine-232/ alanine polymorphism in a bovine gene encoding acyl-CoA:diacylglycerol acyltransferase (DGAT1) with variation at a quantitative trait locus for milk fat content. Proceedings of the National Academy of Sciences of the United States of America 99: 9300-9305 